MTPH Journal, Volume 4, No. 2, September 2020

\title{
HUBUNGAN STATUS PERKAWINAN DAN STATUS NUTRISI DENGAN FUNGSI KOGNITIF LANSIA DI WILAYAH KERJA PUSKESMAS MANUKAN KULON KOTA SURABAYA
}

\author{
Mahstika Raina Angie Yolanda \\ Departemen Epidemiologi, Fakultas Kesehatan Masyarakat, Universitas Airlangga Surabaya \\ Email: mahstikaraina@gmail.com
}

\begin{abstract}
The development of the population in the category of elderly people in Indonesia can bring negative and positive impacts if the population in the elderly category is still active and productive within the healthy condition it means positive impact occurs. Elderly is an age group that is susceptible to changes due to the ageing process. One of the problems that are often encountered in the elderly is the problems related to mental or psychological health. Reduction of cognitive function in mild to dementia levels can be found in older people over the age of 65 years by $10 \%$ and the age group of more than $85 \%$ by $50 \%$. This study was an analytic observational study with a crosssectional research design. The data used are primary data obtained from 52 elderly people who met the inclusion criteria for this study. Data collection includes characteristic data, measurement of cognitive function, nutritional status and physical activity. The data analysis tools used in this study are Ratio Prevalence (RP) value and statistical tests using Chi-Square. The results showed that the elderly who experienced cognitive impairment was $38.5 \%$. Respondents with elementary, middle school and non-school education experienced a decline in cognitive function $(p=0.013)$ with a value of $R P=1.84$. Respondents who did not have a partner experienced a decline in cognitive function $(p=0.039)$. Respondents with normal nutritional status and malnutrition did not experience a decline in cognitive function $(p=0.194)$. The level of education and marital status are significantly related to the cognitive function of the elderly. Families and health workers should provide support so that the elderly do not experience cognitive impairment.
\end{abstract}

Keywords: Elderly, Cognitive Function, Marital Status and Nutritional Status

\begin{abstract}
ABSTRAK
Perkembangan jumlah populasi penduduk berkategori lansia di Indonesia mampu membawa dampak negative maupun positif. Memiliki dampak positif jika penduduk kategori lansia masih aktif dan produktif serta dalam kondisi sehat. Lansia merupakan kelompok usia yang rentan mengalami perubahan-perubahan akibat proses penuaan. Salah satu permasalahan yang sering dijumpai pada lansia selain adalah permasalahan yang berkaitan dengan kesehatan mental atau psikologis. Pengurangan fungsi kognitif dalam tingkat ringan sampai demensia dapat ditemukan pada orang tua dengan kelompok umur lebih dari 65 tahun sebesar 10\% dan kelompok umur lebih dari 85\% sebesar $50 \%$. Penelitian ini merupakan penelitian observasional analitik dengan desain penelitian cross sectional. Data yang digunakan merupakan data primer yang didapatkan dari 52 lansia yang memenuhi kriteria inklusi untuk penelitian ini. Pengumpulan data meliputi data karakteristik, pengukuran fungsi kognitif, status nutrisi dan aktivitas fisik. Analisis data yang digunakan dalam
\end{abstract}


penelitian ini adalah mengunakan perhitungan nilai Ratio Prevalance (RP) dan uji statistik menggunakan Chi Square. Hasil penelitian menunjukkan bahwa lansia yang mengalami penurunan fungsi kognitif sebesar 38,5\%. Responden berpendidikan SD, SMP dan tidak sekolah mengalami penurunan fungsi kognitif ( $\mathrm{p}=0.013$ ) dengan nilai $\mathrm{RP}=1,84$. Responden yang tidak memiliki pasangan mengalami penurunan fungsi kognitif $(\mathrm{p}=0,039)$. Responden dengan status nutrisi normal maupun malnutrisi tidak mengalami penurunan fungsi kognitif $(\mathrm{p}=0,194)$. Tingkat pendidikan dan status perkawinan berhubungan secara signifikan dengan fungsi kognitif lansia. Keluarga dan tenaga kesehatan sebaiknya memberikan dukungan agar lansia tidak mengalami penurunan fungsi kognitif.

Kata kunci: Lansia, Fungsi Kognitif, Status Perkawinan dan Status Nutrisi

\section{PENDAHULUAN}

Definisi lanjut usia berdasarkan Peraturan Pemerintah Republik indonesia Nomor 43 Tahun 2004 adalah seseorang yang telah mencapai usia 60 (enam puluh) tahun keatas. Perkembangan ratio jumlah penduduk lansia pada sebuah populasi di negara maju maupun berkembang cenderung membesar dikarenakan penurunan angka kelahiran (fertalitas) dan kematian (mortalitas) disertai dengan bertambahnya angka harapan hidup (life expected) yang berdampak perubahan secara keseluruhan pada struktur penduduk. Peningkatan gizi, kemajuan tingkat pendidikan dan sosial ekonomi yang semakin baik serta sanitasi yang lebih modern secara langsung berdampak pada proses penuaan penduduk.

Pertumbuhan lansia, kelompok penduduk berusia 60 tahun ketas, sebesar 7 persen sudah terjadi semenjak tahun 2015. Fenomena ini terjadi di seluruh penjuru dunia. Hasil proyeksi Kemenkes RI pada tahun 2017 di Indonesia terdapat 23,66 juta populasi kelompok penduduk lansia . Pada tahun 2020 diperkirakan populasi tersebut naik menjadi 27,08 juta populasi kelompok penduduk lansia. tahun $2025(33,69$ juta), tahun 2030 (40,95 juta) dan tahun 2035 $(48,19 \text { juta })^{1}$.

Besarnya jumlah penduduk lansia di Indonesia di masa depan memberikan berbagai macam dampak pada berbagai tingkatan masyarakat. Jika penduduk lansia berada dalam keadaan sehat, aktif dan produktif hal ini akan berkontribusi positif terhadap masyarakat. Disisi lain, jika lansia memiliki masalah penurunan kesehatan yang berakibat pada peningkatan biaya pelayanan kesehatan, peningkatan disabilitas, penurunan pendapatan/ penghasilan, lingkungan yang tidak ramah terhadap penduduk lansia dan tidak adanya dukungan sosial.

Didapat angka kesakitan sebesar 28,62\% pada tahun 2015, artinya bahwa terdapat sekitar 28 lansia mengalami kondisi sakit dari setiap 100 orang lansia. Informasi dari Pusat Data dan Informasi Kementerian Kesehatan RI tahun 2013, penyakit degeneratif merupakan masalah kesehatan terbesar lansia. Terdapat $75 \%$ lansia penderita penyakit degeneratif tidak dapat 
beraktivitas, jumlah ini merupakan hasil prediksi pada tahun $2050^{2}$. Lansia merupakan kelompok usia yang rentan mengalami perubahanperubahan akibat proses penuaan. Salah satu permasalahan yang sering dijumpai pada lansia selain kesehatan fisik adalah permasalahan yang berkaitan dengan kesehatan mental atau psikologis $^{2}$.

Kesehatan mental yang baik untuk individu didefinisikan sebagai kondisi dimana individu terbebas dari segala jenis gangguan jiwa, dan kondisi dimana individu dapat berfungsi secara normal dalam menjalankan hidupnya, khususnya dalam menyesuaikan diri untuk melakukan kegiatan sehari-sehari. Menurut definisi WHO, kesehatan mental didefinisikan sebagai kondisi dari kesejahteraan yang disadari individu, yang di dalamnya terdapat kemampuan untuk mengelola tekanan kehidupan yang wajar, untuk bekerja secara produktif, serta berperan aktif di komunitasnya.

Terdapat ciri-ciri perubahan yang dikaitkan dengan proses penuaan, yang diakibatkan oleh kehilangan fungsi kognitif yang bersifat bertahap (gradual loss). Lansia akan mengalami perubahan-perubahan fisik diantaranya perubahan sel, sistem pendengaran, sistem persarafan, sistem penglihatan, sistem pengaturan suhu tubuh, sistem respirasi, sistem kardiovaskuler, sistem genitourinari, sistem gastrointestinal, sistem endokrin, sistem muskuloskeletal, disertai juga dengan perubahan-perubahan mental menyangkut perubahan daya ingat ${ }^{3}$. Adanya pengurangan fungsi kognitif yang terjadi pada lansia, meliputi berkurangnya kemampuan fisik, berkurangnya fungsi intelektual, berkurangnya efisiensi tranmisi saraf di otak menyebabkan proses informasi melambat dan banyak informasi yang tidak tertangkap selama transmisi, berkurangnya kemampuan mengumpulkan dan menangkap informasi baru dan mengingat informasi dari memori, serta kemampuan mengingat kejadian masa lalu lebih baik dibandingkan kemampuan mengingat kejadian yang baru saja terjadi ${ }^{4}$.

Penurunan performa secara menyeluruh pada fungsi sistem saraf pusat dipercaya sebagai kontributor utama perubahan dalam kemampuan kognitif dan efisiensi dalam pemrosesan informasi. Sekitar $50 \%$ orang tua pada usia yang lebih dari 85 tahun dan $10 \%$ orang tua yang berusia lebih dari 65 tahun akan mengalami gangguan fungsi kognitif, dimana akan dijumpai gangguan yang sifatnya ringan sampai terjadinya demensia ${ }^{5}$.

Menurut The U.S Departement of Health and Human Services, selain karena penambahan usia, kemampuan kognitif yang terganggu dapat terjadi karena beberapa faktor, diantaranya seperti genetik, tingkat pendidikan, racun, cedera otak, kurangnya aktivitas fisik serta adanya penyakit kronis seperti Diabetes Mellitus, stroke, dan jantung ${ }^{6}$. Menurut Eliopoulus, kemampuan kognitif ditentukan oleh beberapa hal,yaitu status kesehatan, pengalaman hidup, dan gaya hidup, yang 
dimaksud dengan gaya hidup adalah kegiatan rutin setiap hari yang dilakukan seseorang? Gaya hidup yang sehat bagi lansia didefinisikan sebagai semua kegiatan yang bertujuan untuk pemenuhan kebutuhan nutrisi yang baik, olahraga, dan latihan serta istirahat dan tidur yang cukup serta tidak merokok ${ }^{8}$. Menurut Azizah, kemampuan kognitif seseorang dipengaruhi oleh beberapa faktor seperti merokok, konsumsi alkohol, depresi, dukungan sosial,kurang melakukan aktivitas fisik, dan gangguan fungsi fisik ${ }^{1}$.

Selain aktivitas fisik, nutrisi yang baik juga mampu meningkatkan kesehatan lansia dan menghambat berkurangnya fungsi kognitif. Beberapa penelitian menyebutkan bahwa pemenuhan zat gizi mikro yang baik akan memelihara fungsi kognitif pada lansia. Dari hasil penelitian yang dilakukan oleh Rahmawati, menunjukkan bahwa pemenuhan asupan zat gizi mikro, vitamin $\mathrm{C}$ dan vitamin $\mathrm{E}$ yang cukup ternyata memiliki hubungan yang bermakna dengan fungsi kognitif lansia ${ }^{9}$. Hal senada juga ditemukan pada penelitian Zoghbi dkk, mereka menemukan bahwa lansia yang memiliki status nutrisi yang baik juga memiliki fungsi kognitif yang baik ${ }^{10}$.

Pernikahan membawa dukungan emosional, orang yang sudah menikah memiliki orang kepercayaan untuk mendukung dan mendengarkan serta peduli terhadap kesejahteraan dan kesehatan pasangannya. Hal semacam itu secara umum membuat seseorang lebih sehat, lebih bahagia dan dapat mengurangi efek stress bagi kesehatan mental dan fisik. Selain itu kualitas pernikahan juga berpengaruh pada kesehatan seseorang, dapat mempercepat penuaan dan menimbulkan penyakit fisik serta keterbatasan fungsional kesehatan mental ${ }^{11}$.

Dukungan dalam sebuah perkawinan dapat mengurangi stress dan gejala depresi bagi pria maupun wanita. Menurut teori stressbuffering hypothesis, kehadiran pasangan dapat mengurangi reaksi emosional terhadap stres. Pernikahan juga memungkinkan orang untuk terampil mengelola stress ${ }^{12}$.

Menurut jenis kelamin, pola status perkawinan penduduk lansia perempuan berbeda dengan lansia laki-laki. Lansia laki-laki lebih banyak yang berstatus kawin $(82,71 \%)$ Sedangkan lansia perempuan lebih banyak yang berstatus cerai mati $(59,15 \%)$. Hal ini ditemukan keterkaitan antara usia harapan hidup perempuan yang lebih tinggi dibandingkan dengan usia harapan hidup laki-laki, sehingga persentase lansia perempuan yang berstatus cerai mati lebih banyak dibandingkan dengan lansia laki-laki. Satu hal yang menarik dari status perkawinan lansia adalah persentase yang cukup tinggi dari lansia perempuan yang berstatus cerai. Sebaliknya lansia laki-laki yang bercerai umumnya segera kawin lagi ${ }^{2}$.

Berbagai program dan kebijakan yang dijalankan pemerintah di antaranya dituliskan dalam Peraturan Pemerintah Nomor 43 Tahun 2004 tentang Pelaksanaan Upaya Peningkatan 
Kesejahteraan Lanjut Usia, yang antara lain meliputi: 1) Layanan keagamaan dan mental spiritual seperti pembangunan sarana ibadah dengan pelayanan ketersediaan bagi lanjut usia; 2) Layanan kesehatan dengan cara peningkatan upaya penyembuhan (kuratif), diperluas pada bidang pelayanan geriatrik/gerontologik; 3) Layanan untuk prasarana umum, yaitu kemudahan dalam mendapatkan penggunaan fasilitas umum, keringanan biaya, kemudahan dalam melakukan perjalanan, penyediaan fasilitas rekreasi dan olahraga khusus; 4) Kemudahan dalam penggunaan fasilitas umum, seperti pelayanan administrasi pemerintah (Kartu Tanda Penduduk seumur hidup), pelayanan kesehatan pada sarana kesehatan milik pemerintah, pelayanan dan keringanan biaya untuk pembelian tiket perjalanan, akomodasi, pembayaran pajak, penyediaan tempat duduk khusus, penyediaan loket khusus, penyediaan kartu wisata khusus, yang mendahulukan para lanjut usia ${ }^{2}$.

Posyandu lansia adalah pos pelayanan terpadu untuk para usia lanjut di suatu wilayah yang sebelumnya sudah disepakati, yang digerakkan oleh masyarakat dimana mereka bisa mendapatkan pelayanan kesehatan. Posyandu lansia merupakan program pengembangan kebijakan pemerintah melalui pelayanan kesehatan bagi lansia. Posyandu lansia diselenggarakan melalui program Puskesmas dengan melibatkan peran serta lansia, keluarga lansia, tokoh masyarakat setempat dan organisasi sosial saat penyelenggaraannya. Posyandu lansia merupakan fasilitas pelayanan kesehatan yang berada di desa atau kelurahan yang bertujuan meningkatkan kesehatan masyarakat khususnya warga yang berusia lanjut. Posyandu lansia adalah wadah pelayanan bagi kaum usia lanjut yang dilakukan dari, oleh, dan untuk kaum usia lanjut yang menitikberatkan pada pelayanan promotif dan preventif tanpa mengabaikan upaya kuratif dan rehabilitatif. Posyandu lansia merupakan upaya kesehatan lansia yang mencakup kegiatan pelayanan kesehatan yang bertujuan mewujudkan masa tua bahagia dan produktif.

Puskesmas Manukan Kulon merupakan puskesmas yang terletak di Kota Surabaya bagian barat. Berdasarkan data yang tercatat di Dinas Kesehatan Kota Surabaya, puskesmas Manukan Kulon memiliki jumlah lansia dan posyandu lansia terbanyak yaitu 3.399 orang dan 24 posyandu lansia. Cakupan pelayanan lansiapun juga tinggi. Jumlah lansia dan posyandu lansia terbanyak ini menjadikan tempat ini digunakan sebagai tempat penelitian.

Berdasarkan hal tersebut, maka penelitian ini bertujuan untuk mengetahui hubungan antara status perkawinan dan status nutrisi dengan fungsi kognitif lansia. Diharapkan hasil penelitian ini dapat memberikan pengetahuan kepada lansia mengenai nutrisi dalam makanan dan kegiatan yang mencegah penurunan fungsi kognitif. Selain itu, para lansia lebih termotivasi untuk melakukan perbaikan nutrisi mereka. 


\section{METODE PENELITIAN}

Penelitian ini menggunakan jenis penelitian yang bersifat analitik observasional dan menggunakan rancang bangun cross sectional dengan pendekatan kuantitatif. Populasi dalam penelitian ini adalah semua lanjut usia (lansia) berusia 60-74 tahun yang merupakan peserta aktif posyandu lansia yang bertempat tinggal di wilayah kerja Puskesmas Manukan Kulon. Kriteria eksklusi dalam penelitian ini adalah lansia yang sedang atau pernah menderita penyakit kronis dan yang pernah mengalami cedera kepala.

Perhitungan jumlah sampel dengan rumus besar sampel untuk pengujian hipotesis proporsi (1 sampel) ditemukan sebesar 52 responden. Responden diambil secara acak (probability) dengan teknik simple random rampling menggunakan kocokan untuk menentukan posyandu lansia yang akan dijadikan tempat penelitian. Setelah itu untuk penentuan sampel, menggunakan daftar anggota yang ada di posyandu lansia tersebut.

Variabel bebas dalam penelitian ini adalah status perkawinan dan status nutrisi. Variabel terikat pada penelitian ini adalah fungsi kognitif lansia. Data dikumpulkan dengan instrumen penelitian berupa kuesioner. Data primer dikumpulkan menggunakan kuesioner yang ditanyakan langsung kepada responden. Data sekunder berupa data yang didapatkan dari Puskesmas Manukan Kulon berdasarkan dokumen yang ada di Puskesmas yang ditanyakan pada pemegang program posyandu lansia.

Instrument dalam penelitian ini menggunakan MNA (Mini-Nutritional Assessment) dan MMSE (Mini Mental State Examination). Instrument MNA digunakan untuk mengukur status nutrisi. Klasifikasi status nutrisi berdasarkan skor yang didapatkan dari instrument, yaitu normal (skor lebih dari sama dengan 12) dan malnutrisi (skor <12). MMSE digunakan untuk mengukur fungsi kognitif lansia. Klasifikasi fungsi kognitif berdasarkan skor yang didapatkan dari instrument, yaitu normal (skor lebih dari sama dengan 24) dan penurunan fungsi kognitif (skor <24).

Data yang telah terkumpul dianalisis secara univariat dan bivariat. Analisis univariat dilakukan untuk mendeskripsikan variabel secara tunggal dalam bentuk persentase dan Tabel distribusi frekuensi yang berisi tentang umur, jenis kelamin dan pendidikan terakhir responden. Setelah itu akan dilakukan uji bivariat dengan menggunaka chi-square yang bertujuan untuk melihat apakah ada hubungan antar variabel. Bila hasil nilai dari uji tersebut menunjukkan nilai $\mathrm{p}<0,05$ maka ada hubungan antar variabel tersebut signifikan, maka dapat disimpulkan ada hubungan antar variabel. 


\section{HASIL DAN PEMBAHASAN}

\section{Usia Responden}

Tabel 1. Distibusi Usia Responden di wilayah kerja Puskesmas Manukan Kulon Surabaya 2018

\begin{tabular}{lcr}
\hline \multirow{2}{*}{ Usia } & \multicolumn{2}{c}{ Jumlah $(\mathrm{n}=52)$} \\
\cline { 2 - 3 } & Frekuensi & Persentase (\%) \\
\hline 60-64 tahun & 4 & 7,69 \\
65-69 tahun & 23 & 44,23 \\
70-74 tahun & 25 & 48,08 \\
\hline Total & 52 & 100,00 \\
\hline
\end{tabular}

Berdasarkan Tabel 1 dapat dilihat bahwa sebagian besar responden berumur 70-74 tahun yaitu sebanyak 48,08\%. Pemilihan usia ini berdasarkan klasifikasi lansia berdasarkan WHO yang menyatakan usia 60-74 tahun merupakan klasifikasi lanjut usia (elderly).

\section{Jenis Kelamin}

Tabel 2. Distribusi Jenis Kelamin Responden di Wilayah Kerja Puskesmas Manukan Kulon Surabaya 2018

\begin{tabular}{lcr}
\hline Jenis & \multicolumn{2}{c}{ Jumlah $(\mathrm{n}=52)$} \\
\cline { 2 - 3 } Kelamin & Frekuensi & Persentase (\%) \\
\hline Laki-laki & 25 & 48,08 \\
Perempuan & 27 & 51,92 \\
\hline Total & 94 & 100,00 \\
\hline
\end{tabular}

Jenis kelamin responden sebagian besar adalah perempuan yaitu sebanyak $51,92 \%$.

\section{Pendidikan Terakhir}

Tabel 3. Distribusi Pendidikan Terakhir Responden di Wilayah Kerja Puskesmas Manukan Kulon Surabaya 2018

\begin{tabular}{ccr}
\hline Pendidikan & \multicolumn{2}{c}{ Jumlah $(\mathrm{n}=52)$} \\
\cline { 2 - 3 } & Frekuensi & Persentase(\%) \\
\hline Tidak sekolah & 3 & 5,76 \\
SD & 11 & 21,15 \\
SMP & 15 & 28,85 \\
\hline
\end{tabular}

\begin{tabular}{ccr}
\hline \multirow{2}{*}{ Pendidikan } & \multicolumn{2}{c}{ Jumlah $(\mathrm{n}=52)$} \\
\cline { 2 - 3 } & Frekuensi & Persentase $(\%)$ \\
\hline SMA & 13 & 25,00 \\
Diploma & 5 & 9,62 \\
S1 & 5 & 9,62 \\
\hline Total & 52 & 100,00 \\
\hline
\end{tabular}

Berdasarkan Tabel 3 dapat dilihat bahwa responden sebagian besar berpendidikan terakhir SMP sebanyak 28,85\%, sedangkan penggunaan MKJP, sebagian kecil responden tidak sekolah yaitu sebanyak $5,76 \%$.

\section{Hubungan Usia dan Fungsi Kognitif Lansia}

Tabel 4. Hubungan Antara Usia dan Fungsi Kognitif Lansia di Wilayah Kerja Puskesmas Manukan Kulon Surabaya 2018

\begin{tabular}{lcccccc}
\hline \multirow{2}{*}{ Usia } & \multicolumn{4}{c}{ Fungsi kognitif } & \multirow{2}{*}{ Jumlah } \\
\cline { 2 - 6 } & \multicolumn{2}{c}{ Normal } & \multicolumn{2}{c}{ Penurunan } & & \\
\cline { 2 - 6 } & $\mathrm{n}$ & $\%$ & $\mathrm{n}$ & $\%$ & $\mathrm{n}$ & $\%$ \\
\hline 60-69 Th & 17 & 63,0 & 10 & 37,0 & 27 & 100,0 \\
$70-74 \mathrm{Th}$ & 15 & 60,0 & 10 & 28,6 & 25 & 100,0 \\
\hline Sig & 1 & & & & & \\
\hline
\end{tabular}

Pada Tabel 4 dapat dilihat pada variabel usia menunjukkan bahwa responden yang berusia 60-69 tahun dan 70-74 tahun sebagian besar memiliki fungsi kognitif normal. Hasil uji statistik chi square nilai $p$-value=1. Hasil statistik tersebut menunjukkan tidak ada hubungan antara usia dengan fungsi kognitif pada lansia.

Hal ini sama dengan penelitian Rahmawati, et al., menunjukkan bahwa usia responden tidak berhubungan dengan fungsi kognitif ${ }^{9}$. Hal ini tidak sesuai dengan penelitian yang ada dilakukan oleh Constanca, et al., yang menunjukkan bahwa bertambahnya umur 
seseorang beriringan dengan penurunan fungsi kognitif $^{13}$. Hal serupa juga diungkapkan pada penelitian yang dilakukan Beydoun, et al., bahwa responden yang berusia tua memiliki hasil tes kognitif buruk dibandingkan dengan responden berusia muda ${ }^{14}$. Pada penelitian Ritchie, et al., juga menyebutkan bahwa penurunan fungsi kognitif akan terjadi pada usia 80 ke atas ${ }^{15}$. Pada penelitian ini tidak terjadi hubungan yang signifikan antara usia dengan fungsi kognitif karena responden berusia 60-74 tahun.

\section{Hubungan Jenis Kelamin dengan Fungsi Kognitif Lansia}

Tabel 5. Hubungan Antara Jenis Kelamin dengan Fungsi Kognitif Lansia di Wilayah Kerja Puskesmas Manukan Kulon Surabaya 2018

\begin{tabular}{lcccccc}
\hline \multirow{2}{*}{ Jenis } & \multicolumn{4}{c}{ Fungsi Kognitif } & \multirow{2}{*}{ Jumlah } \\
\cline { 2 - 6 } Kelamin & Normal & \multicolumn{2}{c}{ Penurunan } & & \\
\cline { 2 - 6 } & $\mathrm{n}$ & $\%$ & $\mathrm{n}$ & $\%$ & $\mathrm{n}$ & $\%$ \\
\hline Laki-laki & 19 & 76,0 & 6 & 24,0 & 25 & 100 \\
Perempuan & 13 & 48,1 & 14 & 51,9 & 27 & 100 \\
\hline \multicolumn{1}{c}{ sig } & 0,076 & & & & \\
\hline
\end{tabular}

Sebagian besar responden laki-laki memiliki fungsi kognitif normal. Responden perempuan lebih banyak mengalami penurunan fungsi kognitif. Hasil pengujian statistik chi square didapat nilai $p$-value sebesar 0,076 . Hasil statistik tersebut menunjukkan tidak ada hubungan antara jenis kelamin dengan fungsi kognitif pada lansia.

Penelitian ini sesuai dengan penelitian yang dilakukan oleh Rahmawati, et al., yang menunjukkan bahwa tidak ada hubungan antara jenis kelamin dengan fungsi kognitif lansia ${ }^{9}$. Namun pada penelitian ini penurunan fungsi kognitif lebih banyak terjadi pada perempuan $(51,90 \%)$. Hal ini sesuai dengan penelitian Zaninotto, et al., yang menyatakan bahwa lakilaki dan perempuan sama-sama berisiko untuk mengalami penurunan fungsi kognitif. Hal yang menyebabkan perempuan mengalami penurunan fungsi kognitif adalah ketidakaktifan fisik dan kurangnya mobilitas ${ }^{16}$. Pada laki-laki penurunan fungsi kognitif karena kadar lemak. cenderung memiliki risiko lebih tinggi terhadap terjadinya gangguan fungsi kognitif dibandingkan lakilaki.

Hal lain diungkapkan oleh EnglerChiurazzi, et al., penurunan fungsi kognitif disebabkan terjadi penurunan hormon estrogen pada perempuan menopause. Hormon ini memegang peranan penting dalam memlihara fungsi otak sehingga penurunan hormon estrogen dapat meningkatkan risiko penyakit neurodegeneratif ${ }^{17}$. Penyakit neurodegeneratif adalah perubahan yang diakibatkan oleh kerusakan yang berlangsung secara progresif, bersifat umum dan irreversibel. Penyakit neurodegenerasi dan penuaan diawali dengan munculnya tanda-tanda kerusakan yang hampir sama yaitu kerusakan mulai dari tingkat molekul, yaitu DNA, protein, lipid sampai dengan kerusakan pada tingkat seluler dan organ-organ yang pada akhirnya memperpendek umur biologis ${ }^{18}$. 
Hubungan Status Perkawinan Dengan

\section{Fungsi Kognitif Lansia}

Tabel 6. Hubungan Antara Status Perkawinan Dengan Fungsi Kognitif Lansia di Wilayah Kerja Puskesmas Manukan Kulon Surabaya 2018

\begin{tabular}{ccccccc}
\hline \multirow{2}{*}{ Pendidikan } & \multicolumn{4}{c}{ Fungsi Kognitif } & \multirow{2}{*}{ Jumlah } \\
\cline { 2 - 6 } & \multicolumn{2}{c}{ Normal } & \multicolumn{2}{c}{ Penurunan } & & \\
\cline { 2 - 6 } & $\mathrm{n}$ & $\%$ & $\mathrm{n}$ & $\%$ & $\mathrm{n}$ & $\%$ \\
\hline PT dan SMA & 19 & 82,6 & 4 & 17,4 & 23 & 100 \\
\hline $\begin{array}{l}\text { SMP, SD, } \\
\text { tidak sekolah }\end{array}$ & 13 & 44,8 & 16 & 55,2 & 29 & 100 \\
\hline \multicolumn{1}{c}{ sig } & 0,013 & & & & & \\
\hline
\end{tabular}

Tabel 6. diatas menunjukkan bahwa responden yang memiliki tingkat pendidikan dari SMA sampai Perguruan tinggi sebagian besar memiliki fungsi kognitif normal. Responden yang tidak sekolah sampai tingkat pendidikan SMP mengalami penurunan fungsi kognitif. Hasil uji statistik chi square nilai $p$ value $=0,013$. Hasil statistik tersebut menunjukkan ada hubungan antara tingkat pendidikan dengan fungsi kognitif pada lansia. Nilai Ratio Prevalence (RP) untuk variabel ini adalah 1,84. Maka dapat disimpulkan responden dengan pendidikan SMP, SD atau tidak sekolah lebih berisiko sebesar 1,84 kali mengalami penurunan fungsi kognitif dibandingkan dengan responden berpendidikan SMA dan Perguruan Tinggi.

Hasil penelitian ini sesuai dengan penelitian yang dilakukan oleh Akaputra \& Prasanty menunjukkan bahwa tingkat pendidikan ada hubungan dengan fungsi kognitif $^{18}$. Responden dengan pendidikan yang rendah lebih banyak mengalami gangguan pada fungsi kognitif dibandingkan dengan responden dengan pendidikan yang tinggi.

Penelitian yang dilakukan oleh Sundariyati, Ratep, \& Westa juga menunjukkan bahwa tingkat pendidikan berhubungan dengan fungsi kognitif ${ }^{19}$. Orang dengan tingkat pendidikan yang lebih rendah maka orang tersebut cenderung melakukan pemeliharaan kesehatan yang kurang baik dari pada kelompok yang memiliki pendidikan lebih tinggi sehingga tidak mampu mempertahankan hidupnya lebih lama. Perkembangan kemampuan kognitif seperti penalaran, logika, dan pemikiran abstrak serta kemampuan mencegah hilangnya hubungan dan meningkatkan hubungan antar neuron, hal tersebut dapat dicapai dengan pendidikan.

\section{Hubungan Status Perkawinan Dengan}

\section{Fungsi Kognitif Lansia}

Tabel 7. Hubungan Antara Status Perkawinan Dengan Fungsi Kognitif Lansia Di Wilayah Kerja Puskesmas Manukan Kulon Surabaya 2018

\begin{tabular}{lcccccc}
\hline \multirow{2}{*}{$\begin{array}{c}\text { Status } \\
\text { perkawinan }\end{array}$} & \multicolumn{4}{c}{ Fungsi Kognitif } & \multirow{2}{*}{ Jumlah } \\
\cline { 2 - 6 } & \multicolumn{2}{c}{ Normal } & \multicolumn{2}{c}{ Penurunan } & \\
\cline { 2 - 6 } & $\mathrm{n}$ & $\%$ & $\mathrm{n}$ & $\%$ & $\mathrm{n}$ & $\%$ \\
\hline Ada & 26 & 72,2 & 10 & 27,8 & 36 & 100 \\
$\begin{array}{l}\text { suami/istri } \\
\text { Tidak ada } \\
\text { suami/istri }\end{array}$ & 6 & 37,5 & 10 & 62,5 & 16 & 100 \\
\hline \multicolumn{1}{c}{ sig } & 0,039 & & & & \\
\hline
\end{tabular}

Berdasarkan Tabel 7. menunjukkan bahwa responden yang memiliki pasangan (suami/istri) sebagian besar memiliki fungsi kognitif normal. Sebagian besar responden yang tidak memiliki pasangan (suami/istri) mengalami penurunan 
fungsi kognitif. Hasil uji statistik menggunkan chi square didapat nilai p-value sebesar 0,039. Hasil statistik tersebut menunjukkan ada hubungan antara status perkawinan dengan fungsi kognitif pada lansia. Nilai Ratio Prevalence (RP) untuk variabel status perkawinan adalah 1,93. Maka dapat disimpulkan bahwa responden yang tidak memiliki pasangan (suami/istri) lebih berisiko sebesar 1,93 kali mengalami penurunan fungsi kognitif dibandingkan dengan responden yang memiliki pasangan (suami/istri).

Rahmawati, et al., mengemukakan bahwa seseorang yang memiliki pasangan dan pernah menikah pada umumnya mempunyai seseorang untuk membantu dalam kondisi stres dan depresi sehingga hal ini akan berpengaruh terhadap fungsi kognitifnya ${ }^{9}$. Seperti hasil penelitian Constanca, et al., status perkawinan diduga berpengaruh terhadap fungsi kognitif serta seseorang yang kehilangan pasangan atau hidup sendiri akan berpengaruh terhadap penurunan fungsi kognitif ${ }^{13}$. Menurut Sutinah \& Maulani, seseorang yang berstatus duda/janda atau tidak menikah berisiko hidup sendiri, dimana hidup sendiri juga merupakan faktor risiko terjadinya depresi $^{20}$. Lansia yang masih memiliki pasangan hidup akan memiliki tempat untuk saling berbagi dan mendukung dalam menghadapi masa tua, sehingga memiliki risiko depresi yang lebih rendah.

\section{Hubungan Status Nutrisi Dengan Fungsi Kognitif Lansia}

Tabel 8. Hubungan Antara Status Nutrisi Dengan Fungsi Kognitif Lansia di Wilayah Kerja Puskesmas Manukan Kulon Surabaya 2018

\begin{tabular}{cccccccc}
\hline \multirow{2}{*}{ Status } & \multicolumn{4}{c}{ Fungsi Kognitif } & \multirow{2}{*}{ Jumlah } \\
\cline { 2 - 5 } Nutrisi & \multicolumn{2}{c}{ Normal } & \multicolumn{3}{c}{ Penurunan } & & \\
\cline { 2 - 6 } & $\mathrm{n}$ & $\%$ & $\mathrm{n}$ & $\%$ & $\mathrm{n}$ & $\%$ \\
\hline Normal & 20 & 71,4 & 8 & 28,6 & 28 & 100 \\
Malnutrisi & 12 & 50,0 & 12 & 50,0 & 24 & 100 \\
\hline sig & 0,194 & & & & & \\
\hline
\end{tabular}

Tabel 8. diatas menunjukkan bahwa responden yang memiliki status nutrisi normal sebagian besar memiliki fungsi kognitif normal. Responden yang tergolong malnutrisi memiliki persentase seimbang antara fungsi kognitif normal dan yang mengalami penurunan. Hasil pengujian statistik menggunakan chi square didapat nilai p-value sebesar 0,194. Hasil statistik tersebut menunjukkan tidak ada korelasi antara nutrisi dan fungsi kognitif pada lansia.

Hasil penelitian ini tidak sesuai dengan penelitian yang dilakukan oleh Sandersa, et al., mengungkapkan bahwa mereka yang malnutrisi menunjukkan penurunan fungsi kognitif yang lebih buruk dibandingkan dengan mereka tidak malnutrisi ${ }^{21}$. Status nutrisi yang tidak normal disebabkan berkurangnya nafsu makan sehingga konsumsi zat antioksidan juga berkurang sehingga menyebabkan penurunan fungsi kognitif. Hal ini disampaikan oleh penelitian yang dilakukan oleh Beydoun, et al., yang menunjukkan bahwa antioksidan dapat 
menghambat reaksi neurodegenerasi sehingga mencegah gangguan kognitif ${ }^{14}$.

\section{SIMPULAN DAN SARAN}

\section{Simpulan}

Hasil penelitian dapat disimpulkan bahwa ada hubungan yang bermakna antara status perkawinan dengan fungsi kognitif lansia dimana nilai $p$ lebih kecil dari nilai $\alpha$ yaitu 0,039 $<0,05$. Disamping itu, tidak ada hubungan yang bermakna antara status nutrisi dengan fungsi kognitif lansia. Hal ini berdasarkan nilai $p=0,194>0,05$. Tingkat pendidikan dan status perkawinan berhubungan secara signifikan dengan fungsi kognitif lansia.

\section{Saran}

Keluarga dan tenaga kesehatan sebaiknya memberikan dukungan agar lansia tidak mengalami penurunan fungsi kognitif

\section{REFERENSI}

1. Azizah, L. Keperawatan Lanjut Usia. Yogyakarta: Graha Ilmu. 2011.

2. Kemenkes RI. Gambaran Kesehatan Lanjut Usia di Indonesia, Jakarta: Pusat Data dan Informasi. 2013.

3. Watson, R. Perawatan Pada Lansia. Jakarta: EGC. 2013.

4. Setiati S, Harimurti K, Roosheroe AG. Proses Menua dan Implikasi Kliniknya. Dalam: Sudoyo, A.W., Setiyohadi, B., Alwi, I., Simadibrata, M., dan Setiati, S., ed. Buku Ajar Ilmu Penyakit Dalam. Jakarta: Pusat Penerbitan Ilmu Penyakit Dalam Fakultas Kedokteran Universitas Indonesia, 2006. 1335-1340.
5. Bandiyah, S. Lanjut Usia dan Keperawatan Gerontik. Yogyakarta: Nuha Medika. 2009.

6. Departement of Health and Human Services. Physical activity and health older adults, Washington DC: Pennsylvania Avenue: The U.S Departement of Health and Human Services. 2011.

7. Eliopoulus, C. Gerontological Nursing Fifth Edition. Philadelphia: Lippiincott Williams \& Wilkins. 2005.

8. Wallace RJ, Griffith DE, Antimycobacterial Agents. Infectious Diseases. In: Harrison's Principles of Internal Medicine. Fauci AS, Braunwald E, Kasper DL, et al edts. New York: Mc graw Hill Medicine; 2008: 10326.

9. Rahmawati, A., Pramantara, . I. D. P. \& Purba, M. B. Asupan zat gizi mikro dengan fungsi kognitif pada lanjut usia. Jurnal Gizi Klinik Indonesia, 2012. 8(4), pp. 195-201.

10. Zoghbi, M. E. Association between cognitive function and nutritional status in elderly:A cross-sectional study in three institutions of Beirut-Lebanon. Geriatric Mental Health Care, 2012. 1(4), pp. 73-81.

11. Jen-Hao Chen, P., Linda J. Waite, P. \& Diane S. Lauderdale, P. Marriage, Relationship Quality, and Sleep among U.S. Older Adults. J Health Soc Behav, 2015. 56(3), p. 356-377.

12. Beam, C. R., Dinescu, D., Emery, R. E. \& Turkheimer, E. A Twin Study on Perceived Stress, Depressive Symptoms, and Marriage. J Health Soc Behav, 2017. 58(1), pp. 37-53.

13. Constanca, P., Oscar, R. \& Pedro, S. Cognitive impairment in old people living in the community. Arch Gerontol Geriatr, 2010. 51(2), pp. 121-124.

14. Beydoun, M.A. Ethnic diff erences in dairy and related nutrient consumption among US adults and their association with obesity, central obesity, and the metabolic syndrome. Am J Clin Nutr., 2008. 87(6): 1914-1925

15. Goeldner, C. R. Ritchie, J. R. Brent. Tourism Principles Practices Philophies. 7th edition. New Jersey: John Wiley \& Sons Inc. 2009. 
16. Gale, C.R, Deary, I.J, Wardle, J, Zaninotto, P, Batty, G.D. Cognitive Ability and Personality as Predictors of Participation in a National Colorectal Cancer Screening Programe: the English Longitudinal Study of Agening. J. Epidemiol Communiy Helath, 2015;69:530-535.

17. Engler-Chiurazzi, E.B., Brown, C.M., Povroznik, J.M., Simpkins, J.W. Estrogen as Neuroprotectans: Estrogenic Actions in the Context of Cognitive Aging And Brain Injury. Progress in Neurobiology. Elsevier. 2016.

18. Sunarno. The Gluttathion Role As Antioxidant in Inhibition of Neurodegenerative Disease and Brain Aging. Jurusan Biologi Fakultas MIPA Universitas Diponegoro , 2009. 1(2), pp. 185-207.

19. Sundariyati, I., Wayan Ratep, dan Nyoman Westa. Gambaran Faktor-Faktor Yang Mempengaruhi Status Kognitif Pada Lansia Di Wilayah Kerja Puskesmas Kubu II, Januari-Februaru 2014. Jurnal Universitas Udayana. 2014.

20. Sutinah \& Maulani. Hubungan Pendidikan, Jenis Kelamin Dan Status Perkawinan Dengan Depresi Lansia. Journal Endurance. 2017. 2 (2). p.210

21. Sanders, R. A. Adolescent psychosocial, social, and cognitive development. 2013. 34 (8). http://pedsinreview.aappublications.org/

22. Kemenkes RI. Analisis Lansia Indonesia. Jakarta: Pusat Data dan Informasi. 2017.

23. Sutikno, E. Faktor-faktor yang Berhubungan dengan Gangguan Kesehatan Mental pada Lansia Studi Cross Sectional pada Kelompok Jantung Sehat Surya Group Kediri. Jurnal Wiyata, 2015. 2(1), pp. 1-8. 